\title{
SELECTION VIA MIXED MODELS IN SEGREGATING GUAVA FAMILIES BASED ON YIELD AND QUALITY TRAITS ${ }^{1}$
}

\author{
SILVANA SILVA RED QUINTAL ${ }^{2}$, ALEXANDRE PIO VIANA ${ }^{3}$, BIANCA MACHADO CAMPOS ${ }^{4}$, \\ MARCELO VIVAS ${ }^{5}$, ANTONIO TEIXEIRA DO AMARAL JÚNIOR ${ }^{6}$
}

\begin{abstract}
Aiming at the generation of new guava varieties with superior attributes, we conducted this study adopting the REML/BLUP procedure at individual level. Seventeen segregating guava families were evaluated in a randomized-block design with two replicates and 12 plants per plot. Families were obtained after controlled biparental pollination. The studied individuals showed high genotypic variance for fruit weight (FW), total yield (YLD), and ascorbic acid content (AAC). The heritability coefficients of the mean of progenies led to high progeny-selection accuracy for pulp yield (PY), soluble solids content (SSC), in addition to FW, YLD, and AAC; moderate accuracy for fruit acidity (FA) and SSC/FA ratio; and low accuracy for mesocarp thickness (MT) and $\mathrm{pH}$. Selection among families $\left(\hat{h}^{2} m p\right)$ indicated the highest values for FW, PY, YLD, SSC, and AAC, revealing that, for the present study, this practice would be effective, since these traits allowed for the highest selection accuracy values among families. As for the ranking of individuals, families originating from crosses UENF $1835 \times$ UENF 1834, UENF $1831 \times$ UENF 1832, and UENF 1831 $\times$ UENF 3739 stood out, occupying the first positions for most traits.
\end{abstract}

Index terms: Psidium guajava, variability, REML/BLUP.

\section{SELEÇÃO VIA MODELOS MISTOS EM FAMÍLIAS SEGREGANTES DE GOIABEIRA BASEADA EM CARACTERÍSTICAS DE PRODUTIVIDADE E DE QUALIDADE}

RESUMO - Visando à obtenção de novas variedades de goiaba com atributos superiores, este trabalho foi conduzido e analisado pelo procedimento REML/BLUP, em nível de indivíduos.Foram avaliadas 17 famílias segregantes de goiabeira, seguindo o delineamento experimental de blocos casualizados, com 2 repetições, com 12 plantas por parcela. As famílias foram obtidas após polinizações biparentais controladas. Os indivíduos estudados apresentaram elevada variância genotípica para peso de fruto (PF), produtividade (PRD) e teor de ácido ascórbico (TAA). As magnitudes dos coeficientes de herdabilidade da média das progênies conduziram a um alto valor de acurácia para seleção de progênies para rendimento de polpa (RP), teor de sólidos solúveis (TSS), além de PF, PRD e TAA; moderado para acidez do fruto (AF) e para a relação TSS/AF, e baixo em espessura do mesocarpo (EM) e pH. Averiguou-se que a seleção entre famílias ( $\left.\hat{h}^{2} m p\right)$ apresentou os maiores valores para PF, RP, PRD, TSS e TAA, mostrando-se que, para o presente estudo, a seleção entre família seria efetiva, já que estas características foram as que permitiram maiores valores de acurácia seletiva entre famílias. Quanto ao ordenamento dos indivíduos, observa-se um destaque para as famílias provenientes do cruzamento entre UENF 1835 x UENF 1834; UENF 1831 x UENF 1832; UENF 1831 x UENF 3739, que ocupam as primeiras posições no rankeamento para a maioria das características. Termos para indexação: Psidium guajava, variabilidade, REML/BLUP.

\footnotetext{
'(Paper 217-15). Received September 28, 2015. Accepted March 01, 2016.

${ }^{2}$ DsC Genetic and Plant Breeding, Universidade Estadual do Norte Fluminense Darcy Ribeiro (UENF), Laboratório de Melhoramento Genético Vegetal (LMGV). Campos dos Goytacazes - RJ, Brazil. E-mail: silvanared@hotmail.com

${ }^{3}$ DSc - Plant Science, Universidade Estadual do Norte Fluminense Darcy Ribeiro (UENF), Laboratório de Melhoramento Genético Vegetal (LMGV). Campos dos Goytacazes - RJ, Brazil. pirapora@uenf.br

${ }^{4}$ Dsc Genetic and Plant Breeding, Estadual do Norte Fluminense Darcy Ribeiro (UENF), Laboratório de Melhoramento Genético Vegetal (LMGV). Campos dos Goytacazes - RJ. E-mail: biancamachado@hotmail.com

${ }^{5}$ Dsc Genetic and Plant Breeding, Estadual do Norte Fluminense Darcy Ribeiro (UENF), Laboratório de Melhoramento Genético Vegetal (LMGV). Campos dos Goytacazes - RJ. E-mail:mrclvivas@hotmail.com

${ }^{6}$ Dsc Genetic and Plant Breeding, Estadual do Norte Fluminense Darcy Ribeiro (UENF), Laboratório de Melhoramento Genético Vegetal (LMGV). Campos dos Goytacazes - RJ. E-mail: amaraljr@pq.cnpq.br
} 


\section{INTRODUCTION}

Guava (Psidium guajava L.) is a plant widespread across all tropical regions of the globe (RODRÍGUEZ et al., 2010). Though information on guava production in the world is limited, FAO (2014) data show that the main producing countries are India, China, Kenya, Thailand, Indonesia, Pakistan, Mexico, Brazil, Bangladesh, Egypt, and the Philippines, which, together, account for $80 \%$ of the world guava production.

The increased guava production in Brazil is related not only to the growing consumption of fruit in its fresh form, but also products originating from its industrialization, such as juices, jams, sweets, among others. In this scenario, the valuation of the product as raw material for the industry and the increased consumption in the natural form of fruit ('table consumption') have brought about changes in the production and commercialization systems. Therefore, breeding programs must be intensified to generate varieties that meet the market demands for both table consumption and the industry (MITRA, 2010). Based on this premise, it is speculated that a study of genetic breeding in guava, based on the selection of plants originating from seeds, may enable the generation of cultivars with adequate traits for fresh consumption and for industrial purposes (FERNANDES-SANTOS et al., 2010).

There is also a need for selecting superior individuals and, in this regard, the mixed-models methodology applied in the genetic assessment of individuals candidate to selection is used to describe data from experiments whose structure involves some fixed and some random factors, irrespective of the mean and the error. In this sense, REML/BLUP is the recommended analytical procedure in that it provides an estimate of variance components through restricted maximum likelihood (REML) and predicts genetic values by the best linear unbiased prediction (BLUP). This methodology has been adopted in several plant species and in diverse population structures like coconut (FARIAS NETO et al., 2009), rice (BORGES et al., 2010), sugarcane (PEDROZO et al., 2011), common bean (BALDISSERA et al., 2012), açaí (FARIAS NETO et al., 2012), papaya (VIVAS et al., 2014a,b), and others.

Continuing the work of selection in a segregating full-sibling population of $P$. guajava, a study was conducted to estimate the genetic parameters and obtain predictions of genotypic values, via the REML/BLUP procedure, at individual level, aiming at the production of new commercial varieties with superior attributes.

\section{MATERIAL AND METHODS}

The following 17 segregating guava families were evaluated: 1) UENF $1834 \times$ UENF 1833; 2) UENF $1831 \times$ UENF 1830; 3) UENF $1831 \times$ UENF 1832; 4) UENF $1831 \times$ UENF 1837; 5) UENF 1831 $\times$ UENF 3839; 6) UENF $1833 \times$ UENF 1832; 7) UENF $1834 \times$ UENF $1839 ; 8$ ) UENF $1835 \times$ UENF 1834; 9) UENF $1834 \times$ UENF 1836; 10) UENF 1836 $\times$ UENF 1835 ; 11) UENF $1833 \times$ UENF $1836 ; 12$ ) UENF $1831 \times$ UENF $1835 ; 13$ ) UENF $1833 \times$ UENF 1835 ; 14) UENF $1832 \times$ UENF 1833 ; 15) UENF $1834 \times$ UENF 1837 ; 16) UENF $1834 \times$ UENF 1831 and 17) UENF $1832 \times$ UENF 1835 . The crosses between parents were established taking into account information of genetic diversity obtained by Pessanha et al. (2011).

The families were obtained after controlled biparental pollinations of selected guava genotypes. Crosses were performed in Bom Jesus do Itabapoana - RJ, Brazil. The parents used in the crosses presented a considerable degree of heterozygosis, because the plants were selected at orchards originating from seedlings grown from seeds, and studies conducted by Pessanha et al. (2011) found considerable genetic diversity among these parents. The seeds obtained from the fruits from these crosses originated a segregating population of wide genetic variability.

After the 17 segregating guava families were obtained, a randomized-block experimental design with two replicates and 12 plants per plot was established. Plants were allocated with 1.50 $\mathrm{m}$ spacing between each other and $3.50 \mathrm{~m}$ between rows. Irrigation was applied by micro sprinklers, individually. Fertilization was performed according to the soil analysis, in split sessions, after pruning for harvest, with three doses of $83 \mathrm{~g}$ of urea plus $138 \mathrm{~g}$ potassium chloride applied per plant applied every 30 days. Phytosanitary control was performed for rust control, by the application of copper-based products. During the fruiting phase, 10 fruits were sampled per individual, harvested at maturation stage 1 , when their peel was a dark green color (AZZOLINI et al., 2004).

The following variables were evaluated in the individuals that had over 10 fruits (96 individuals): fruit weight (FW), measured with a semi-analytical scale, with data expressed as grams; mesocarp thickness (MT), determined by taking two measurements from the sides at the mid-region of the fruit, using a caliper ruler, with results expressed as $\mathrm{mm}$; pulp yield (PY), calculated as the ratio between fruit weight and pulp mass (obtained by subtracting the placental mass from the fruit weight); soluble 
solids content (SSC), obtained by reading the juice extracted by hand pressing from a sample of fruit pulp tissue, with readings performed in a portable ATAGO N1 refractometer in the $0-32{ }^{\circ}$ Brix range; $\mathrm{pH}$, determined using an Orion $410 \mathrm{pH}$ meter; fruit acidity (FA), determined according to the method adopted by Carvalho et al. (1990), with results expressed as a percentage of citric acid per $100 \mathrm{~g}$ of pulp; soluble solids content/fruit acidity ratio (SSC/ FA), calculated by dividing SCC by FA; ascorbic acid content (AAC), determined by the method of Carvalho et al. (1990), with results expressed in $\mathrm{mg}$ of ascorbic acid per $100 \mathrm{~g}$ of pulp; and total yield (YLD), estimated after pruning the plants for harvest, by multiplying the number of fruits per plant by the average weight of the fruits, with results expressed as $\mathrm{g} / \mathrm{plant}$. The individuals were evaluated at three different times: February 2011, January 2012, and October 2012. For each time, the evaluation was based on the number of plants that produced at least ten fruits per plant. The number of individuals evaluated in common at the three times was 96 .

The variables were analyzed using SelegenReml/Blup software (RESENDE, 2002a), employing the individual BLUP procedure and the following model: $\mathrm{y}=\mathrm{Xr}+\mathrm{Zg}+\mathrm{Wp}+\epsilon$, where $\mathrm{y}$ is the vector of data; $r$ is the vector of replicate effects (assumed as fixed) added to the overall mean; $g$ is the vector of the individual genotypic effects (assumed as random); $p$ is the vector of plot effects (random); and $\epsilon$ is the vector of errors or residuals (random). Uppercase letters represent the incidence matrices for the said effects.

The following variance components were estimated (individual REML): $\sigma^{2}$ - genotypic variance among progenies of full siblings, corresponding to $1 / 2$ of the additive genetic variance plus $1 / 4$ of the genetic variance of dominance, ignoring epistasis; $\sigma_{\text {plot }}^{2}$ - environmental variance among plots; $\sigma^{2}$ within environmental variance within plot; $\sigma_{\mathrm{p}}^{2}$ - individual phenotypic variance; $h^{2}{ }_{a}=\mathrm{h}^{2}$ - individual narrowsense heritability, obtained ignoring the fraction $(1 / 4)$ of genetic variance of dominance; $c^{2}$ plot $=c^{2}$ - coefficient of determination of the plot effects; $h^{2}$ - mean heritability of progenies, assuming complete survival; Acprog - accuracy in the selection of progenies, assuming complete survival; and $\hat{\mathrm{h}}^{2}{ }_{\mathrm{ad}}$ additive heritability within plot, obtained ignoring the fraction (1/4) of genetic variance of dominance and overall mean of the experiment.

\section{RESULTS AND DISCUSSION}

There was a greater participation of genotypic variance among progenies in the individual phenotypic variance for fruit weight (FW) and pulp yield (PY) (Table 1) as well as soluble solids (SSC) and ascorbic acid (AAC) contents (Table 2), suggesting it is possible to select progenies with high yield and that produce better-quality fruit. This fact is related to the very composition of the segregating population under evaluation, given that the parents that composed the crosses were divergent and possibly presented most of their loci in heterozygosis for the traits assessed. Composing populations through this type of crossing may be highly advantageous for fruit breeders, since they respond as an $\mathrm{F}_{2}$ population, able to undergo a selection process with possibilities of advantageous genetic gains.

High soluble solids contents are desirable in guava fruit for both fresh consumption and for the industry. In the case of fruits intended for the industry, higher SSC values are positively correlated with lower processing costs (GONZAGA NETO et al., 1986). With regard to the amount of ascorbic acid, NASCIMENTO et al. (1998) stated that elevated acidity is desirable, since there is a reduction in the addition of artificial acidifiers for processing. By contrast, when the fruit is aimed at fresh consumption, low acidity levels are a desirable feature (PAIVA et al., 1997).

The highest estimates in narrow-sense heritability $\left(h^{2}{ }_{a}\right)$ were detected for fruit weight (FW), pulp yield (PY), total yield (YLD), soluble solids content (SSC), and ascorbic acid content (AAC). For the other traits, $h^{2}$ estimates were of low magnitude and did not surpass their respective standard deviations (Tables 1 and 2). Overall, the use of selection procedures based on mixed models is justified, because even with low-heritability traits, the favorable genetic gains were predicted, and the genotypes have potential for selection.

Comparing individual selection, also called massal selection, with the selection of families, we observed lower selection efficiency for practically all traits evaluated, considering that their respective individual heritabilities $\left(\hat{h}^{2} a\right)$ were lower than the heritability estimates at the level of progeny means $\left(\hat{h}_{m p}\right)$ (Tables 1 and 2$)$. As for selection accuracy, high estimates were detected for fruit weight (FW), pulp yield (PY), total yield (YLD), soluble solids content (SSC), and ascorbic acid content (AAC) (Tables 1 and 2). High accuracy values indicate high precision in the access to the actual genetic variation; they are a correlation between the predicted and actual values. 
Addressing accuracy values, Resende and Duarte (2007) classified this statistics as very high (Accuracy $\geq 0.90)$, high $(0.70 \leq$ Accuracy $\leq 0.90)$, moderate $(0.50 \leq$ Accuracy $\leq 0.70)$, and low (Accuracy $\leq 0.50)$. According to Resende (2002b), variables that present the highest accuracy values indicate good genetic control in the expression of the traits under study, demonstrating good precision of the analyzed results.

The obtained results suggest the possibility of producing superior guava progenies with elevated yield values. Yield is one of the main selection criteria in the breeding of plants, for most crops. It is not by chance that studies have been carried out to establish methods that allow for an anticipated selection of progenies with a higher degree of safety. However, although yield is the main variable aimed at by the breeder in most crops, he or she must also take into consideration the qualitative aspects of the fruit before a variety is released to the producer, so that it can be accepted with no management or logistics problems, pleasing the final consumer.

The pulp yield (PY) in the present study had a higher mean than those obtained by several authors (REBOUÇAS et al., 2008; NATALE et al., 2009). According to Lima et al. (1999), fruits with PY values greater than $70 \%$ should be selected; this corroborates the potential of the population studied in this experiment, which, overall, showed a higher mean than that value (Table 1). However, it is still below the $94 \%$ required by the market. We must stress that, in the present study, we did not consider the juicier layer (endocarp), where the seeds are located, which might, depending on pulping, increase the pulp yield.

Considering the soluble solids content, the average ${ }^{\circ}$ Brix value found in this study was within the limit established by Natale et al. (2009); i.e., between 8 and $12{ }^{\circ}$ Brix (Table 2). The same result was obtained for the average $\mathrm{pH}$ found in the present study, which is within the range cited by Yusof (1990) for several guava varieties and ideal for fresh consumption. $\mathrm{pH}$ values higher than 3.5 suggest the need for adding edible organic acids during the fruit processing to provide it with better quality of final, industrialized product.

Titratable acidity is an important trait in the appreciation of the preservation state of a food product. This quantity tends to increase as the fruit ripens until its physiological development is complete, and when it is mature, this variable decreases. In the current study, the average total titratable acidity of citric acid per $100 \mathrm{~g}$ of pulp was much lower than that suggested by Pereira and Nachtigal (2002). However, Lima et al. (1999) claimed that acidity is not a limiting factor to the selection of genotypes if other traits are considered satisfactory. Here, the SSC/FA ratio, which is an indicator of the degree of fruit sweetness, averaged 23.01 (Table 2). For comparison purposes, we can cite the studies of Lima et al. (2002) and Pereira and Nachtigal (2002), who obtained SSC/FA ratios of 20.08 and 18.60 , respectively, which are values that provide a highly sweet taste to the fruit.

Considering the yield-related attributes, of all individuals assessed, 98.96\% for fruit yield and $100 \%$ for mesocarp thickness, pulp yield, and total yield showed new means with performance superior to the overall mean (Table 3). As for the fruit-quality attributes, of the individuals assessed, $92.70 \%$ for ascorbic acid content, $94.79 \%$ for SSC/FA, $98.96 \%$ for $\mathrm{SSC}$, and $100 \%$ for $\mathrm{pH}$ and fruit acidity showed new means with performance superior to the overall mean (Table 4).

The amplitude, i.e., the difference between the highest and the lowest new mean of the genotypes in the ranking, was $11.50 \%, 0.47 \%, 0.93 \%, 20.17 \%$, and $4.18 \%$ for FW, MT, PY, YLD, and SSC, respectively. This low amplitude shown by some traits was likely due to the narrowing of the predicted means caused by REML/BLUP, which causes the existing differences between genotypes to be lower and result more from genetic than environmental effects (RESENDE, 2002b).

With respect to the selected individuals (20 best), family eight stood out with $35 \%$ for $\mathrm{FW}, 60 \%$ for MT, and $55 \%$ of the individuals ranked for YLD (Table 3), in addition to leading in the first nine positions for MT and YLD. This prominence of progeny eight indicates that, for this family, MT and YLD had very similar means, despite the segregation of individuals originating from the same cross. Family four also stood out with $35 \%$ for the MT variable (Table 3). Such results for these progenies are highly promising, given the interest in these traits for the fresh fruit and industrial markets.

Family five stood out with $60 \%$ among all individuals ranked for the PY variable, showing to be a family with elevated selection potential for this trait (Table 3). Family two also showed great results for this variable, with $25 \%$ of the selected individuals. For the SSC variable, the best ranking individual belonged to progeny three, in 10 outstanding positions; i.e., in $50 \%$ of the ranking (Table 4). A $13.64 \%$ increase in the overall mean was noted for the first ranked individual of this progeny. This progeny also occupied the first position and more than 40\% of individuals selected for SCC/FA, revealing it to be material of very sweet taste (Table 4). 
The best individual ranked for the $\mathrm{pH}$ variable belongs to progeny five, and had an increase of only $0.06 \%$ in the overall mean for the trait, whereas the 20th individual (progeny eight) showed a $0.04 \%$ increase, but progeny five represented $10 \%$ of the selected individuals, while eight represented $40 \%$ of them. Little gain over the overall mean is observed for these traits; however, according to the descriptions of Yusof (1990), the mean values found here are within the desirable range.

TABLE 1- Estimates of variance components and coefficients of determination for yield-related attributes (FW - fruit weight [g], MT - mesocarp thickness [mm], PY - pulp yield [\%], and YLD - total yield [g/plant]) obtained after an evaluation of 96 individuals in 17 segregating guava families. Campos dos Goytacazes, RJ, Brazil

\begin{tabular}{lcccc}
\hline \multicolumn{1}{c}{ Parameter } & FW & MT & PY & YLD \\
\hline Genotypic variance among progenies & 446.424 & 0.021 & 0.817 & 1614833.30 \\
Environmental variance among plots & 273.091 & 0.813 & 0.024 & 1457526.89 \\
Residual variance within plot & 1216.935 & 1.903 & 4.941 & 7462775.00 \\
Individual phenotypic variance & 1936.452 & 2.738 & 5.783 & 10535135.18 \\
Individual narrow-sense heritability & $0.46 \pm 0.28$ & $0.02 \pm 0.05$ & $0.28 \pm 0.22$ & $0.31 \pm 0.23$ \\
Coefficient of determination of plot effects & 0.141 & 0.296 & 0.004 & 0.138 \\
Heritability of the progeny mean & 0.677 & 0.038 & 0.718 & 0.574 \\
Accuracy in progeny selection & 0.823 & 0.197 & 0.847 & 0.758 \\
Additive heritability within plot & 0.366 & 0.011 & 0.165 & 0.216 \\
Overall mean & 239.430 & 15.302 & 80.243 & 6072.504 \\
\hline
\end{tabular}

TABLE 2- Estimates of variance components and coefficients of determination for fruit-quality attributes (SSC - soluble solids content [ $\left.{ }^{\circ} \mathrm{Brix}\right], \mathrm{pH}$ - fruit $\mathrm{pH}, \mathrm{FA}$ - fruit acidity [\% citric acid/100 g of pulp], SSC/FA - soluble solids content/fruit acidity ratio, and AAC - ascorbic acid content [\% ascorbic acid/100 g of pulp]) obtained after an evaluation of 96 individuals in 17 segregating guava families. Campos dos Goytacazes, RJ, Brazil

\begin{tabular}{lccccc}
\hline \multicolumn{1}{c}{ Parameter } & SSC & pH & FA & SSC/FA & AAC \\
\hline Genotypic variance among progenies & 0,236 & 0,0001 & 0,000097 & 0,666 & 123,867 \\
Environmental variance among plots & 0,085 & 0,008 & 0,000016 & 0,809 & 27,782 \\
Residual variance within plot & 0,577 & 0,024 & 0,003 & 11,505 & 286,453 \\
Individual phenotypic variance & 0,900 & 0,033 & 0,003 & 12,981 & 438,103 \\
Individual narrow-sense heritability & $0,52 \pm 0,30$ & $0,02 \pm 0,05$ & $0,06 \pm 0,10$ & $0,10 \pm 0,13$ & $0,56 \pm 0,31$ \\
Coefficient of determination of plot effects & 0,095 & 0,265 & 0,004792 & 0,062 & 0,063 \\
Heritability of the progeny mean & 0,749 & 0,047 & 0,315 & 0,372 & 0,795 \\
Accuracy in progeny selection & 0,865 & 0,217 & 0,562 & 0,610 & 0,892 \\
Additive heritability within plot & 0,409 & 0,012 & 0,030 & 0,057 & 0,432 \\
Overall mean & 8,369 & 4,318 & 0,371 & 23,013 & 37,086 \\
\hline
\end{tabular}


TABLE 3- Ranking by new means predicted via REML/BLUP (individuals ordered and selected/respective families) of the 20 best genotypes selected from a segregating guava population for yieldrelated attributes (FW - fruit weight, MT - mesocarp thickness, PY - pulp yield, and YLD - total yield). Campos dos Goytacazes, RJ, Brazil

\begin{tabular}{ccccc}
\hline Order & FW & MT & PY & YLD \\
\hline $\mathbf{1}$ & $284,4173(86 / 13)$ & $15,5831(15 / 8)$ & $82,4765(54 / 5)$ & $10038,9027(67 / 8)$ \\
$\mathbf{2}$ & $281,4021(64 / 8)$ & $15,5736(65 / 8)$ & $82,3034(37 / 2)$ & $9897,8088(64 / 8)$ \\
$\mathbf{3}$ & $278,7960(18 / 8)$ & $15,5694(61 / 8)$ & $82,2150(60 / 5)$ & $9721,8597(16 / 8)$ \\
$\mathbf{4}$ & $276,7281(21 / 9)$ & $15,5659(64 / 8)$ & $82,1632(11 / 5)$ & $9577,7017(65 / 8)$ \\
$\mathbf{5}$ & $275,0515(15 / 8)$ & $15,5605(18 / 8)$ & $82,1219(2 / 2)$ & $9425,8245(62 / 8)$ \\
$\mathbf{6}$ & $273,9154(61 / 8)$ & $15,5546(67 / 8)$ & $82,0942(58 / 5)$ & $9234,5727(63 / 8)$ \\
$\mathbf{7}$ & $273,0882(67 / 8)$ & $15,5500(63 / 8)$ & $82,0670(59 / 5)$ & $9096,7215(66 / 8)$ \\
$\mathbf{8}$ & $272,4519(62 / 8)$ & $15,5465(66 / 8)$ & $82,0444(57 / 5)$ & $8970,1806(15 / 8)$ \\
$\mathbf{9}$ & $271,8586(30 / 1)$ & $15,5437(68 / 8)$ & $82,0196(10 / 5)$ & $8848,4837(17 / 8)$ \\
$\mathbf{1 0}$ & $271,3412(88 / 13)$ & $15,5413(17 / 8)$ & $81,9931(53 / 5)$ & $8745,2103(29 / 1)$ \\
$\mathbf{1 1}$ & $270,8737(69 / 9)$ & $15,5389(62 / 8)$ & $81,9638(12 / 5)$ & $8639,0679(32 / 1)$ \\
$\mathbf{1 2}$ & $270,3061(13 / 6)$ & $15,5355(5 / 3)$ & $81,9344(40 / 2)$ & $8544,0729(26 / 15)$ \\
$\mathbf{1 3}$ & $269,035(22 / 13)$ & $15,5311(37 / 2)$ & $81,9052(9 / 5)$ & $8460,4227(76 / 10)$ \\
$\mathbf{1 4}$ & $269,3096(87 / 13)$ & $15,5271(73 / 10)$ & $81,8792(36 / 2)$ & $8387,1657(18 / 8)$ \\
$\mathbf{1 5}$ & $268,8441(74 / 10)$ & $15,5236(40 / 3)$ & $81,8487(56 / 5)$ & $8321,5637(61 / 8)$ \\
$\mathbf{1 6}$ & $268,4152(73 / 10)$ & $15,5202(13 / 6)$ & $81,8199(5 / 3)$ & $8258,1759(25 / 15)$ \\
$\mathbf{1 7}$ & $268,0344(5 / 3)$ & $15,5171(30 / 1)$ & $81,7913(40 / 3)$ & $8197,4758(22 / 13)$ \\
$\mathbf{1 8}$ & $267,6648(77 / 10)$ & $15,5140(16 / 8)$ & $81,7611(55 / 5)$ & $8136,2347(31 / 1)$ \\
$\mathbf{1 9}$ & $267,3223(65 / 8)$ & $15,5112(74 / 10)$ & $81,7334(35 / 2)$ & $8073,9579(36 / 2)$ \\
$\mathbf{2 0}$ & $266,9792(20 / 9)$ & $15,5085(85 / 12)$ & $81,7074(46 / 3)$ & $8013,4875(2 / 2)$ \\
\hline
\end{tabular}

TABLE 4- Ranking by new means predicted via REML/BLUP (individuals ordered and selected/respective families) of the 20 best genotypes selected from a segregating guava population for fruit-quality attributes (SSC - soluble solids content, $\mathrm{pH}$ - fruit $\mathrm{pH}, \mathrm{FA}$ fruit acidity, SSC/FA - soluble solids content/fruit acidity ratio, and AAC - ascorbic acid content). Campos dos Goytacazes-RJ, Brazil

\begin{tabular}{cccccc}
\hline Order & SSC & pH & FA & SSC/FA & AAC \\
\hline 1 & $9,5016(45 / 3)$ & $4,3212(58 / 5)$ & $0,3795(87 / 13)$ & $23,8435(42 / 3)$ & $80,0965(23 / 14)$ \\
2 & $9,4954(40 / 3)$ & $4,3209(14 / 7)$ & $0,3793(40 / 3)$ & $23,8195(14 / 7)$ & $72,5283(24 / 14)$ \\
3 & $9,4811(41 / 3)$ & $4,3208(17 / 8)$ & $0,3790(46 / 3)$ & $23,7902(45 / 3)$ & $69,1219(29 / 1)$ \\
4 & $9,4391(42 / 3)$ & $4,3208(36 / 2)$ & $0,3788(44 / 3)$ & $23,7599(34 / 2)$ & $66,8662(91 / 15)$ \\
5 & $9,4096(23 / 14)$ & $4,3207(35 / 2)$ & $0,3787(23 / 14)$ & $23,7416(37 / 2)$ & $65,4437(32 / 1)$ \\
6 & $9,3719(90 / 14)$ & $4,3206(15 / 8)$ & $0,3785(9 / 5)$ & $23,7278(70 / 9)$ & $64,4378(8 / 4)$ \\
7 & $9,3396(8 / 4)$ & $4,3206(26 / 15)$ & $0,3784(53 / 5)$ & $23,7163(1 / 2)$ & $63,2434(90 / 14)$ \\
8 & $9,3077(3 / 3)$ & $4,3205(61 / 8)$ & $0,3783(90 / 14)$ & $23,7071(35 / 2)$ & $62,2573(92 / 15)$ \\
9 & $9,2820(5 / 3)$ & $4,3204(1 / 2)$ & $0,3782(41 / 3)$ & $23,6922(12 / 5)$ & $61,3389(47 / 4)$ \\
10 & $9,2562(56 / 5)$ & $4,3204(21 / 9)$ & $0,3780(56 / 5)$ & $23,6798(4 / 3)$ & $60,5735(49 / 4)$ \\
11 & $9,2347(89 / 14)$ & $4,3203(62 / 8)$ & $0,3779(10 / 5)$ & $23,6668(39 / 3)$ & $59,7357(89 / 14)$ \\
12 & $9,2160(46 / 3)$ & $4,3203(70 / 9)$ & $0,3778(47 / 4)$ & $23,6549(38 / 2)$ & $58,9914(46 / 3)$ \\
13 & $9,1989(4 / 3)$ & $4,3203(83 / 12)$ & $0,3777(22 / 13)$ & $23,6442(3 / 3)$ & $58,1610(25 / 15)$ \\
14 & $9,1829(49 / 4)$ & $4,3202(10 / 5)$ & $0,3776(57 / 5)$ & $23,6349(5 / 3)$ & $57,3158(30 / 1)$ \\
15 & $9,1684(39 / 3)$ & $4,3202(67 / 8)$ & $0,3775(43 / 3)$ & $23,6260(2 / 2)$ & $56,5210(78 / 11)$ \\
16 & $9,1538(11 / 5)$ & $4,3202(75 / 10)$ & $0,3774(8 / 4)$ & $23,6182(59 / 5)$ & $55,8233(5 / 3)$ \\
17 & $9,1403(79 / 12)$ & $4,3201(72 / 9)$ & $0,3773(88 / 13)$ & $23,6111(41 / 3)$ & $55,1713(93 / 16)$ \\
18 & $9,1278(24 / 14)$ & $4,3201(68 / 8)$ & $0,3772(77 / 10)$ & $23,6028(72 / 9)$ & $54,5807(48 / 4)$ \\
19 & $9,1156(43 / 3)$ & $4,3201(16 / 8)$ & $0,3772(84 / 12)$ & $23,5945(43 / 3)$ & $54,0450(31 / 1)$ \\
20 & $9,1037(78 / 11)$ & $4,3200(18 / 8)$ & $0,3771(45 / 3)$ & $23,5870(36 / 2)$ & $53,5526(52 / 4)$ \\
\hline
\end{tabular}




\section{CONCLUSION}

The estimates for genetic parameters revealed excellent selection potential of the population and sufficient genetic variability for the genetic breeding of the population in the short and long terms. Families originating from the crosses between UENF $1835 \times$ UENF 1834, UENF $1831 \times$ UENF 1832, and UENF $1831 \times$ UENF 3739 stood out for occupying the first positions in the ranking for most traits. Individual selection of plants may be the recommended strategy for the breeding of the population in question.

\section{ACKNOWLEDGMENTS}

The authors thank UENF, FAPERJ, and $\mathrm{CNPq}$ for the opportunity and resources provided for the development of this study.

\section{REFERENCES}

AZZOLINI, M.; JACOMINO, A.P.; BRON, I.U. Índices para avaliar qualidade póscolheita de goiabas em diferentes estádios de maturação. PesquisaAgropecuáriaBrasileira, Brasília, DF, v. 39, n. 2, p. 139-145, 2004.

BALDISSERA, J.N.C.; BERTOLDO, J.G.; VALENTINI, G.; COAN, M.M.D.; ROZETO, D.S.; GUIDOLIN, A.F.; COIMBRA, J.L.M. Uso do melhor preditor não-viesado (BLUP) na predição de híbridos de feijão. Bioscience Journal, Uberlândia, v. 28 , n. 3, p. 395-403, 2012.

BORGES, V.; SOARES, A.A.; REIS, M.S.; RESENDE, M.D.V.; CORNELIO, V.M.O.; LEITE, N.A.; VIEIRA, A.R. Desempenho genotípico de linhagens de arroz de terras altas utilizando metodologia de modelos mistos. Bragantia, Campinas, v.69, n.4, p.833-841, 2010.

CARVALHO, C.R.L.; MANTOVANI, D.M.B.; CARVALHO, P.R.N.; MORAES, R M.M. Análises químicas de alimentos. Campinas: Institutede Tecnologia de Alimentos. 1990.
FAO. Production quantity: mangoes, mangosteens, guavas. Disponível em: < http:// faostat.fao.org/site/567/DesktopDefault. aspx?PageID=567\#ancor $>$. Acesso em: 20 dez. 2014. FARIAS NETO, J.T.; LINS, P.M.P.; RESENDE, M.D.V.; MULLER, A.A. Seleção genética em progênies híbridas de coqueiro. Revista Brasileira de Fruticultura, Jaboticabal, v. 31,n. 1, p. 190-196, 2009.

FARIAS NETO, J.T.; OLIVEIRA, M.S.P.; RESENDE, M.D.V.; RODRIGUES, J.C.Parâmetros genéticos e ganhos com a seleção de progênies de Euterpe oleracea na fase juvenil. Cerne, Lavras, v. 18, n. 3, p.515-521, 2012.

FERNANDES-SANTOS, C.A.; CUNHACASTRO, J.M.; FRANÇA-SOUZA, F.; ALCÂNTARA-VILARINHO, A.; FERREIRA, F.R.; GOMES-PÁDUA, J.; ESTIGARRIBIABORGES, R.M.; BARBIERI, R.L.; CLARET DE SOUZA, A.D.G.; AMORIM-RODRIGUES, M. Prospecting and morphological characterization of brazilian Psidium germplasm. Acta Horticulturae, The Hague, v. 849, p.63-68, 2010.

GONZAGA NETO, L.; PEDROSA, A.C.; ABRAMOF, L.; BEZERRA, J.E.F.; DANTAS, A.P.; SILVA, H.M.; SOUZA, M.M. Seleção de cultivares de goiabeira (Psidium guajava L.) para fins industriais, na Região do Vale do Rio Moxotó. Revista Brasileira de Fruticultura,Jaboticabal, v. 8, n. 3, p. 55-61, 1986.

LIMA, M.A.C.; ASSIS, J.S.; NETO, L.G. Caracterização dos frutos de goiabeiras e seleção de cultivares na região do sub-médio São Francisco. Revista Brasileira de Fruticultura, Jaboticabal, v. 24, n. 1,p. 273-276, 2002.

LIMA, M.A.; DURIGAN, J.F.; PEREIRA, F.M.; FERRAUDO, A.S. Caracterização físico-química dos frutos de 19 genótipos de goiabeira, obtidos na FCAV-UNESP. Revista Brasileira de Fruticultura, Jaboticabal, v. 21, n. 3, p. 252-257, 1999.

MITRA, S.K. Important Myrtaceae fruit crops. Acta Horticulturae, The Hague, v. 849, p. 33-38, 2010.

NATALE, W.; ROZANE, D.E.; SOUZA, H.A.; AMORIM, D.A. Cultura da goiaba: do plantio à comercialização. Jaboticabal: Funep, 2009. 
NASCIMENTO, T.B.; RAMOS, J.D.; MENEZES, J. B. Características físico-químicas do maracujáamarelo (Passiflora edulis f. flavicarpa Degener) produzido em diferentes épocas. Revista Brasileira de Fruticultura, Jaboticabal, v. 20, n. 1, p. 33-38. 1998.

PAIVA, M.C.; MANICA, I.; FIORAVANÇO, J.C.; KIST, H. Caracterização química dos frutos de quatro cultivares e duas seleções de goiabeira. Revista Brasileira de Fruticultura, Jaboticabal, v. 19, n. 1, p. 57-63, 1997.

PEDROZO, C.A.; BARBOSA, M.H.P.; SILVA, F.L.; RESENDE, M.D.V.; PETERNELLI, L.A. Repeatability of full-sibsugarcane families across harvest and the efficiency of early selection. Euphytica, Wageningen, v. 182, n. 3, p. 423-430, 2011.

PEREIRA, F. M., NACHTIGAL, J. C. Goiabeira. In:BRUCKNER,C.H. (Ed.) Melhoramento de fruteiras tropicais. Viçosa: UFV, 2002. p.267-289.

PESSANHA, P.G.O.; VIANA, A.P.; AMARAL JÚNIOR, A.T.; SOUZA, R.M.; TEXEIRA, M.C.; PEREIRA, M.G. Avaliação da diversidade genética em acessos de Psidum ssp.via marcadores.

RAPD. Revista Brasileira de Fruticultura, Jaboticabal v. 33, n. 1, p. 129-136, 2011.

REBOUÇAS, E.B.R.; GENTIL, D.F.O.; FERREIRA, S.A.N. Caracterização física de frutos e fementes de goiaba-da-Costa-Rica produzidos em Manaus, Amazonas. Revista Brasileira de Fruticultura, Jaboticabal,v. 30, n. 2, p. 546-548, 2008.
RESENDE, M.D.V. Genética biométrica e estatística no melhoramento de plantas perenes. Brasília: Embrapa Informação Tecnológica, 2002b.

RESENDE, M.D.V. Selegen-Reml/Blup - Seleção genética computadorizada: manual do usuário Colombo: Embrapa CNPF, 2002a. 67 p

RESENDE, M.D.V.; DUARTE, J.B. Precisão e controle da qualidade em experimentos de avaliação de cultivares. Pesquisa Agropecuária Tropical, Goiânia, v. 37, n. 3,p. 182-194, 2007.

RODRÍGUEZ, N.N.; VALDÉS, J.J.; RODRÍGURZ, J.A.; VELÁSQUEZ, J.B.; RIVERO, D.; MARTINEZ, F.; GONZALEZ, G.; SOURD, D.G.; GONZALEZ, L.; CANIZARE, J. Genetic resources and breeding o of guava (Psidium guajava L.) in Cuba. Biotecnología Aplicada, La Habana, v. 27, n. 3, p. 238-241, 2010.

VIVAS, M.; SILVEIRA, S.F.; VIANA,A.P.;AMARAL JUNIOR, A.T.; CARDOSO, D. L.; PEREIRA, M.G. Efficiency of circulant diallels via mixed models in the selection of papaya genotypes resistant to foliar fungal diseases. Genetics and Molecular Research, Ribeirão Preto, v. 13, n. 3, p. 4797-4804, 2014a.

VIVAS, M.; SILVEIRA, S.F.; VIVAS, J.M.S.;VIANA, A.P.; AMARAL JUNIOR, A. T.; PEREIRA, M.G. Seleção de progênies femininas de mamoeiro para resistência a mancha-de-phoma via modelos mistos. Bragantia, Campinas, v. 73,n. 4, p. 446-450, 2014 b.

YUSOF, S. Physico-chemical characteristics of same guava varieties in Malaysia. Acta Horticulturae, The Hague, v. 269, p. 301-306, 1990. 